\title{
HUMAN TOXOCARIASIS: A SEROEPIDEMIOLOGICAL SURVEY IN THE MUNICIPALITY OF CAMPINAS (SP), BRAZIL
}

\author{
Francisco ANARUMA FILHO(1), Pedro Paulo CHIEFFI(2,3), Carlos Roberto Silveira CORREA(4), Eide Dias CAMARGO(5), Edilene P. Real da SILVEIRA(5),
} Joana José Brandão ARANHA(5) \& Manoel Carlos S. Almeida RIBEIRO(3)

\begin{abstract}
SUMMARY
The occurrence of human Toxocara infection was evaluated in three neighborhoods of the periphery of the Campinas municipality (Jardim Santa Mônica, Jardim São Marcos and Jardim Campineiro) in 1999. Forty residences and 138 residents were randomly selected by drawing lots and were submitted to a seroepidemiological survey, which included blood collection for the immunoenzymatic detection (ELISA) of anti-Toxocara antibodies and a blood count, and the application of a semi-structured questionnaire for the evaluation of epidemiological data. Significant levels of anti-Toxocara antibodies were detected in $23.9 \%$ of the 1999 samples. No significant difference in the frequency of infection according to age was observed. Environmental contamination with Toxocara eggs was observed in 12.3 and $14.0 \%$ of 57 soil samples collected in the same region in December 1998 and July 1999, respectively. Univariate analysis and multiple logistic regression of the data obtained from the questionnaires and of the results of the serological tests, suggest a significant influence of socioeconomic variables on the frequency of human infection with Toxocara under the conditions prevalent in the study area.
\end{abstract}

KEYWORDS: Human toxocariasis; Toxocara canis; Frequency of infection; Risk factors; Campinas (SP).

\section{INTRODUCTION}

Toxocara canis and T. cati, nematodes of the family Ascaridae, are parasites of the small intestine of canid and felid species, respectively, that can infect humans when their larva-containing eggs are ingested. This zoonosis is called human toxocariasis and represents the main cause of visceral larva migrans $s^{4,5,28,38}$.

Humans are infected upon ingestion of embrionated eggs of these ascarids, consequently harboring third-stage larvae in their tissues ${ }^{6}$, and thus becoming paratenic hosts ${ }^{4,18}$.

In most cases, human infection with Toxocara larvae does not show clinical manifestations and evolves in an asymptomatic manner ${ }^{38}$; however, in some cases, it can cause several alterations such as fever, hepatomegaly, splenomegaly, respiratory symptoms, muscle pain and anorexia, accompanied by elevated eosinophilia and high anti-Toxocara antibody titers ${ }^{1,14,40}$. Ocular manifestations are found in isolated cases, and probably result from a mild parasite burden, as indicated by the low anti-Toxocara antibody titers and mild eosinophilia ${ }^{18}$ that accompany this clinical form of toxocariasis.

The laboratory diagnosis of human Toxocara infection is usually based on the detection of antibodies against metabolic antigens of this ascarid, using immunoenzymatic techniques (ELISA) ${ }^{19}$ which show good sensitivity and specificity, are easy to carry out, inexpensive, and show good reproductivity ${ }^{1,7,32}$. The use of this technique by various researchers has permitted the identification of the cosmopolitan characteristic of human Toxocara infection ${ }^{3,38}$.

The frequency and epidemiology of toxocariasis in different regions of Brazil have been studied by some authors ${ }^{8,32}$, but some aspects of the epidemiology of this disease are still poorly understood. The aim of the present study was to determine the frequency of Toxocara infection and aspects regarding its transmission in a population inhabiting an area at risk of flooding in the municipality of Campinas, and to evaluate its association with clinical signs and symptoms presented or reported by the individuals studied.

\section{MATERIAL AND METHODS}

The study region was located $30 \mathrm{~m}$ from both margins of the Lagoa stream and the Quilombo river, comprising the Jardim Santa Mônica, Jardim São Marcos and Jardim Campineiro neighborhoods, and was delimited according to the criteria established by the Programa de Combate a Enchentes da Prefeitura de Campinas (Campinas Town Hall Project of Combating Flooding), called PROCEN, with an estimated population size of 5,000 inhabitants. 


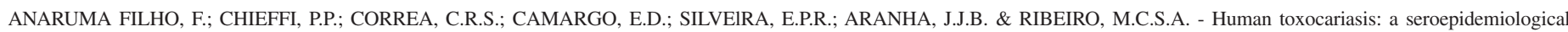
survey in the municipality of Campinas (SP), Brasil. Rev. Inst. Med. trop. S. Paulo, 44(6):303-307, 2002.

The study area showed a heterogenous pattern of occupation, and was predominantly occupied by typical shanty town dwellings intermingled with some brick houses.

Using the Epi-Info (6.04b) software and considering an expected prevalence of $30 \%$ for the occurrence of Toxocara infection and the presence of 5 inhabitants in each home it was calculated a sample of 161 individuals or, at least, 31 residences. A random sample of 40 residences registered by PROCEN and obtained by drawing lots was visited. The residents were informed about the objectives of the study and written informed consent was obtained A semi-structured questionnaire was applied to those who agreed to participate in the study in order to obtain epidemiological data and data characterizing the dwelling and its surrounding area.

Blood samples were collected onto Whatman No. 3 filter paper for the detection of anti-Toxocara antibodies from the finger pulp of 138 individuals (51 males and 87 females, ranging from 3 months to 80 years old) in January 1999, resulting in a sampling loss of $14.3 \%$. Serological examination was carried out at the Serology Section of the Central Laboratory of the Adolfo Lutz Institute using T. canis larva excretion-secretion antigen and the immunoenzymatic technique standardized in this laboratory ${ }^{7}$. The ELISA cut-off had been determined every day using human positive and negative sera.

In addition, 78 blood samples were collected in January 1999 for blood count performed at the Laboratory of the University Hospital of the State University of Campinas.

To determine the frequency of soil contamination by helminth eggs, 57 samples were collected around the selected houses as described by SCHULZ \& KROEGER ${ }^{40}$ and examined as recommended by MASTRANDREA \& MICARELLI ${ }^{31}$.

All participants in the survey were clinically evaluated at the Basic Health Unit of Jardim Santa Mônica and submitted to adequate medical treatment and follow-up when necessary.

The data obtained were submitted to statistical analysis, with the level of significance set at $95 \%(\mathrm{p}=0.05)$. The association between social, demographic and epidemiological variables and the presence of anti-Toxocara antibodies was studied using univariate analysis by determination of the prevalence rate. In addition, variables that were found to be significant upon univariate analysis were analyzed by multivariate logistic regression using the maximum likelihood ratio test based on the stepwise forward method, considering $\mathrm{p}<0.10$ for model entry and at least $\mathrm{p}=0.05$ for permanency.

This study was evaluated and approved by the Ethical Research Committee of UNICAMP School of Medicine (No. 099/98 - CEP/FCM - 12/08/98).

\section{RESULTS}

Table 1 shows the frequencies of anti-Toxocara antibodies obtained during the survey carried out in 1999 according to sex and age.

Toxocara canis eggs were found in 12.3 and $14.0 \%$ of the soil samples
Table 1

Frequency (\%) of Toxocara infection among 138 residents from Jardim Santa Mônica, Jardim São Marcos and Jardim Campineiro, municipality of Campinas (SP), in 1999, according to sex and age

\begin{tabular}{lcc}
\hline Variables & No. examined & Frequency $(\%)$ \\
\hline Sex: & 51 & 23.5 \\
Male & 87 & 24.1 \\
Female & & \\
Age (years): & 65 & 27.7 \\
Less than 15 & 73 & 20.5 \\
15 or more & 138 & 23.9 \\
\hline Total &
\end{tabular}

obtained from the peridomiciliary area in December 1998 and July 1999, respectively, with $T$. canis being the most common helminth species on both occasions (Table 2).

Table 2

Frequency of contamination with helminth eggs in 57 soil samples collected in Jardim Santa Mônica, Jardim São Marcos and Jardim Campineiro, municipality of Campinas (SP), between 1998 and 1999

\begin{tabular}{lcccc}
\hline Helminth species & \multicolumn{2}{c}{$\begin{array}{c}\text { December } \\
\text { No. }\end{array}$} & $\%$ & \multicolumn{2}{c}{ July } & $1999 *$ \\
& 7 & 12.3 & No. & $\%$ \\
\hline Toxocara canis & 3 & 5.3 & 8 & 14.0 \\
Ascaris sp. & - & - & 6 & 10.5 \\
Trichuris sp. & 4 & 7.0 & 2 & 3.5 \\
Ancylostomid-like & 43 & 75.4 & 40 & 70.2 \\
Negative samples & & & & \\
\hline
\end{tabular}

* More than one species per sample

Table 3 shows the result of the univariate analysis regarding the association between the variables investigated and the presence of antiToxocara antibodies at significant levels in the sera examined.

The three variables that were found to be significantly correlated with positive serology for anti-Toxocara antibodies (water treatment, sanitary facilities and a wall around the dwelling), together with the variable soil contact, were submitted to multivariate analysis. In the final model, only the variable sanitary facilities were significantly correlated with Toxocara infection, indicating a lower risk of infection with this ascarid for individuals living in houses connected to the sewer network (odds ratio $=9.02$, confidence interval $=1.95$ to 41.84 ). The variable soil contact was close to significance (odds ratio $=3.70$, confidence interval $=0.96$ to 14.37 ), suggesting a higher risk of Toxocara infection in individuals who admitted this type of contact. No significant correlation with a higher risk of Toxocara infection was observed for the other variables analyzed.

No signs or clinical symptoms had been evidenced in the examined individuals during the study carried out, except for some hematological alterations (Table 3) 


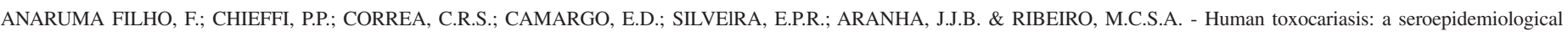
survey in the municipality of Campinas (SP), Brasil. Rev. Inst. Med. trop. S. Paulo, 44(6):303-307, 2002.

Table 3

Frequency of Toxocara infection among residents from Jardim Santa Mônica, Jardim São Marcos and Jardim Campineiro, municipality of Campinas (SP), in 1999 according to the variables investigated

\begin{tabular}{|c|c|c|c|c|}
\hline Variable & & No. & $\%$ & PR \\
\hline \multirow[t]{2}{*}{ Literacy } & Yes & 56 & 23.2 & $1.06(0.55-2.03)$ \\
\hline & No & 61 & 24.6 & \\
\hline \multirow[t]{2}{*}{ Educational level } & Basic incomplete & 61 & 18.0 & $2.22(0.67-7.36)$ \\
\hline & Middle complete & 5 & 40.0 & \\
\hline \multirow[t]{2}{*}{ Contact with soil } & Yes & 83 & 27.7 & $2.77(0.9-8.56)$ \\
\hline & No & 30 & 10.0 & \\
\hline \multirow[t]{2}{*}{ Family income } & Up to $2 \mathrm{MS}$ & 53 & 24.5 & $1.04(0.57-1.92)$ \\
\hline & Above $2 \mathrm{MS}$ & 85 & 23.5 & \\
\hline \multirow[t]{2}{*}{ Water treatment } & None & 102 & 29.4 & $3.49(1.75-17.19)^{*}$ \\
\hline & Filtration & 36 & 8.3 & \\
\hline \multirow[t]{2}{*}{ Sanitary facilities } & Cesspool & 12 & 66.7 & $3.36(1.97-5.72)^{*}$ \\
\hline & Sewer & 126 & 19.8 & \\
\hline \multirow[t]{2}{*}{ Wall around the dwelling } & Yes & 91 & 18.7 & $1.82(1.02-3.27)^{*}$ \\
\hline & No & 47 & 34.1 & \\
\hline \multirow[t]{2}{*}{ Dog's ownership } & Yes & 89 & 27.0 & $1.47(0.74-2.90)$ \\
\hline & No & 49 & 18.4 & \\
\hline \multirow[t]{2}{*}{ Cat's ownership } & Yes & 21 & 14.3 & $1.79(0.60-5.35)$ \\
\hline & No & 117 & 25.6 & \\
\hline \multirow[t]{2}{*}{ Eosinophilia } & Yes & 37 & 24.3 & $1.66(0.65-4.22)$ \\
\hline & No & 45 & 14.6 & \\
\hline \multirow[t]{2}{*}{ Anemia } & Yes & 24 & 29.2 & $1.93(0.79-4.72)$ \\
\hline & No & 53 & 15.1 & \\
\hline
\end{tabular}

PR - Prevalence rate; * Significant; MS - Minimum salary; Eosinophilia and anemia in conformity to (World Health Organization, 1998).

\section{DISCUSSION}

Great advances in the study of human infection with Toxocara larvae were made at the end of the 1970s with the standardization of immunoenzymatic tests (ELISA) and the isolation of metabolic T. canis antigens ${ }^{12,19}$ through in vitro culture of $T$. canis larvae. Since then, seroepidemiological surveys in different countries have shown a cosmopolitan distribution of this zoonosis ${ }^{3,38}$, with varying frequencies which generally reach expressive levels. In developed countries where the prevalence of parasite infections is low, toxocariasis represents the most frequent helminthiasis ${ }^{28}$.

In regions where the frequency of concomitant infection with enteroparasitic helminths such as Ascaris lumbricoides and other nematodes is high, the specificity of the immunoenzymatic test for the detection of anti-Toxocara antibodies was improved by previous absorption of the sera with antigen extract obtained from $A$. lumbricoides or $A$. suum specimens s,9 $^{7,}$ and serological surveys have shown varying but always high frequencies of human Toxocara infection i,28,36,38. $^{3}$.

The frequencies of Toxocara infection observed in the samples obtained in 1999 (Table 1) suggest an elevated circulation of this ascarid in the study area, as confirmed by the detection of eggs in soil samples on both occasions (Table 2). However, it should be noted that the levels observed correspond to intermediate rates between those reported for economically developed regions, whose population presents a high quality of life $\mathrm{e}^{22,26,29,33}$, and areas where the living conditions of the population are highly precarious ${ }^{2,21,30}$.
No significant difference was observed in the frequency of Toxocara infection when the age of the individuals was taken into account (Table 1).

Most serological surveys have shown a predominance of seropositivity in children ${ }^{9,11,15,38}$, a fact probably due to the higher frequency of geophagia in this age group ${ }^{3,20}$. However, some areas with a high prevalence of human Toxocara infection did not show significant differences according to age $^{2}$. With respect to gender, several studies have shown a higher frequency of Toxocara infection in male individuals 13,18,24,36; however, EHRHARD \& KERNBAUM ${ }^{14}$, analyzing 778 clinical cases of visceral and ocular toxocariasis, observed a predominance of women among adult patients, while males predominated among children.

The influence of socioeconomic factors on the occurrence of human Toxocara infection has been emphasized by different authors. In the United States, the frequency of infection among children aged one to 11 years oscillated between 4.6 and $7.3 \%$; however, this rate increased to approximately $30 \%$ when black children of low socioeconomic level were considered ${ }^{22}$. Similar results have been obtained for other regions $s^{7,10,27}$.

Univariate analysis of the present results revealed that a higher frequency of Toxocara infection was associated with variables that ultimately evaluate living conditions of the population, e.g., aspects related to urban infrastructure. Therefore, as indicated in Table 3 , individuals living in houses that possess sewer facilities and walls delimiting the garden, in addition to those who filter the drinking water, 


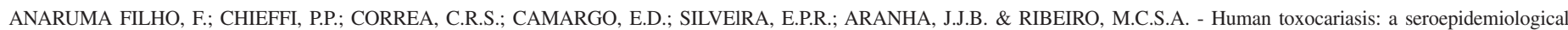
survey in the municipality of Campinas (SP), Brasil. Rev. Inst. Med. trop. S. Paulo, 44(6):303-307, 2002.

showed significantly lower frequencies of Toxocara infection. In addition, a tendency towards lower infection rates was observed for individuals of better educational level, although this trend was not statistically significant. These variables are much more associated with better living conditions than the lower risk of Toxocara infection, except for the presence of a backyard wall.

Although the existence of a wall around the dwelling can also be considered an indicator of a better economic level of the dwelling, it probably protects the area around the house against invasion by stray dogs, which usually show a higher frequency of $T$. canis infection than dogs with an owner ${ }^{2}$. On the other hand, although Toxocara eggs are frequently found in soils from open areas ${ }^{3,38}$, various authors have focused their attention on the importance of contamination of peridomiciliary areas, in particular residential gardens, in the transmission of this ascarid to humans ${ }^{17,23,34,42}$. Therefore, the presence of a wall delimiting the peridomiciliary area, in addition to indicating a better socioeconomic level of the residents, also protects the microenvironment against contamination with Toxocara eggs.

Another interesting finding of the present study was the lack of a significant association between family income and the frequency of Toxocara infection. This result is probably due to the fact that the difference in income between the selected residents was small, since a higher frequency of infection among low-income individuals is usually observed in regions where these differences are pronounced ${ }^{10,22,27}$.

Another variable usually associated with a higher risk of Toxocara infection is contact with soil ${ }^{13,35}$. The results of the present study also point in this direction, although no significant difference in the frequency of Toxocara infection was observed between individuals who admitted contact with soil and those who did not (Table 3). However, a tendency towards a higher frequency was observed for those individuals who usually had contact with soil.

Controversy exists regarding the importance of contact with dogs as a risk factor for human toxocariasis. Some authors reported a higher frequency of infection for individuals who maintained contact with $\operatorname{dog} s^{8,33,39}$, while others did not find any association between ownership or professional contact with dogs and the frequency of Toxocara infection $^{16,25,43}$. Nevertheless, the presence of dogs seems to be more important for the determination of human infection than the presence of cats, since the eradication of dogs, but not cats, in Iceland during the 1940s led to the disappearance of human Toxocara infection in that country at the beginning of the $1980 \mathrm{~s}^{44}$. In the present study, no significant association was observed between ownership of a dog or cat and Toxocara infection.

We also did not observe any association between the occurrence of anemia or eosinophilia and a higher frequency of Toxocara infection in the present study. Although both hematologic alterations have been described for clinical cases of toxocariasis ${ }^{1,28,32}$, most individuals with positive serology and symptoms compatible with this zoonosis are not affected by these alterations ${ }^{37}$.

The variables showing a significant association with a higher frequency of Toxocara infection, in addition to soil contact, were submitted to multivariate analysis, with the presence of sewer facilities in the dwelling being identified as the variable associated with a lower frequency of Toxocara infection (odds ratio $=9.02$, confidence interval $=1.95$ to 41.84 ). Contact with soil showed a tendency towards an association with a higher risk of infection with this ascarid, but this association did not reach statistical significance (odds ratio $=3.70$, confidence interval $=0.96$ to 14.37 ). These results suggest a strong association between living conditions and the occurrence of Toxocara infection in the case of the present study, since the study population consisted a low income group with relatively precarious living conditions. Therefore, variables such as contact with soil and the presence of a wall around the dwelling, which, from an epidemiological point of view, are associated with the transmission of toxocariasis, were found to be nonsignificant in the model employed here.

\section{RESUMO}

\section{Toxocaríase humana: inquérito soroepidemiológico no município de Campinas (SP), Brasil}

Estudou-se a ocorrência de infecção humana por Toxocara em três bairros da periferia do município de Campinas (Jardim Santa Mônica, Jardim São Marcos e Jardim Campineiro). Em 1999 sortearam-se aleatoriamente 40 domicílios e 138 moradores foram submetidos a inquérito soroepidemiológico, que incluiu coleta de sangue para teste imunoenzimático (E.L.I.S.A.) visando pesquisa de anticorpos antiToxocara e hemograma, além de aplicação de questionário semiestruturado para avaliação de dados de interesse epidemiológico. Observou-se presença de anticorpos anti-Toxocara em 23,9\% das amostras, sem ocorrência de diferença significativa quando se considerou a idade ou sexo dos indivíduos examinados. Em 57 amostras de solo da mesma região, coletadas em dezembro de 1998 e novamente em julho de 1999, estudou-se a contaminação ambiental por ovos de Toxocara, verificando-se sua presença em, respectivamente, $12,3 \%$ e $14,0 \%$ das amostras. Análises univariada e multivariada por regressão logística dos dados obtidos a partir dos questionários e dos resultados da sorologia anti-Toxocara mostraram influência significativa de variáveis de ordem sócio-econômica na prevalência de infecção humana por Toxocara, nas condições presentes na área estudada.

\section{REFERENCES}

1. ABE-JACOB, C.M.; PASTORINO, A.C.; PERES, B.A. et al. - Clinical and laboratorial features of visceral toxocariasis in infancy. Rev. Inst. Med. trop. S. Paulo, 36: 1926, 1994.

2. AJAYI, O.O.; DUHLINSKA, D.D.; AGWALE, S.M. \& NJOKU, M. - Frequency of human toxocariasis in Jos, Plateau State, Nigeria. Mem. Inst. Oswaldo Cruz, 95: $147-149,2000$.

3. BARRIGA, O.O. - A critical look at the importance, prevalence and control of toxocariasis and the possibilities of immunological control. Vet. Parasit., 29: 195-234, 1988.

4. BEAVER, P.C. - Toxocariasis (Visceral Larva Migrans) in relation to tropical eosinophilia. Bull. Soc. Path. exot., 55: 555-577, 1962.

5. BEAVER, P.C.; SNYDER, C.H.; CARRERA G. et al. - Chronic eosinophilia due to visceral larva migrans. Pediatrics, 9: 7-19, 1952.

6. BRUNASKÁ, M.; DUBINSKY, P. \& REITEROVÁ, K. - Toxocara canis: ultrastructural aspects of larval moulting in maturing eggs. Int. J. Parasit., 25: 683-690, 1995. 


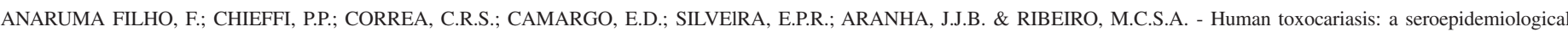
survey in the municipality of Campinas (SP), Brasil. Rev. Inst. Med. trop. S. Paulo, 44(6):303-307, 2002.

7. CAMARGO, E.D.; NAKAMURA, P.M.; VAZ, A.J. et al .- Standardization of DOTELISA, for the serological diagnosis of toxocariasis and comparison of the assay with ELISA. Rev. Inst. Med. trop. S. Paulo, 34: 55-60, 1992.

8. CHIEFFI, P.P.; UEDA, M.; CAMARGO, E.D. et al. - Contacto domiciliar e profissional com cães como fatores de risco para infecção humana por larvas de Toxocara. Rev. Inst. Med. trop. S. Paulo, 30: 379-382, 1988

9. CHIEFFI, P.P.; UEDA, M.; CAMARGO, E.D. et al. - Visceral larva migrans: a seroepidemiological survey in five municipalities of São Paulo State, Brazil. Rev. Inst. Med. trop. S. Paulo, 32: 204-210, 1990.

10. CILlA, G.; PÉREZ TRALlERO, E; GUTIÉRREZ, C.; PART, C. \& GOMARIZ, M. Seroprevalence of Toxocara infection in middle-class and disadvantaged children in northern Spain (Gipuzkoa, Basque County). Europ. J. Epidem., 12 : 541-543, 1996.

11. CONDE GARCIA, L.; MURO ALVAREZ, A. \& SIMON MARTIN, F. - Epidemiological studies on toxocariasis and visceral larva migrans in a zone of Western Spain. Ann. trop. Med. Parasit., 83: 615-620, 1989.

12. CYPESS, R.H.; KAROL, M.H.; ZIDIAN, J.L.; GLICKMAN, L.T. \& GITLIN, D. - Larva specific antibodies in patients with visceral larva migrans. J. infect. Dis., 135: 633640, 1977.

13. DUBIN, S.; SEGALL, S. \& MARTINDALE, J. - Contamination of soil in two city parks with canine nematode ova including Toxocara canis: a preliminary study. Amer. J. publ. Hlth., 65: 1242-1245, 1975.

14. EHRHARD, T. \& KERNBAUM, S. - Toxocara canis et toxocarose humaine. Bull. Inst Pasteur, 77: 225-287, 1979.

15. EMBIL, J.A.; TANNER, C.E.; PEREIRA, L.H. et al. - Seroepidemiologic survey of Toxocara canis infection in urban and rural children. Publ. Hlth. (Lond.), 102: 129133, 1988.

16. GLICKMAN, L.T. \& CYPESS, R.H. - Toxocara infection in animal hospital employees. Amer. J. publ. Hlth., 67: 1193-1195, 1977.

17. GLICKMAN, L.T.; MAGNAVAL, J.F.; DOMANSKI, L.M. et al. - Visceral larva migrans in French adults: a new disease syndrome? Amer. J. Epidem., 125: 1019-1034, 1987.

18. GLICKMAN, L.T. \& SCHANTZ, P.M. - Epidemiology and pathogenesis of zoonotic toxocariasis. Epidem. Rev., 3: 230-250, 1981.

19. GLICKMAN, L.T.; SCHANTZ, P.; DOMBROSKE, R. \& CYPESS, R. - Evaluation of serodiagnostic tests for visceral larva migrans. Amer. J. trop. Med. Hyg., 27: $492-$ 498, 1978.

20. GILLESPIE, S.H. - The epidemiology of Toxocara canis. Parasit. today, 4: 180-182, 1988

21. HAKIM, S.L.; MAK, J.W.; LAM, P.I.; NAZMA, S. \& NORMAZNAH, Y. Seroprevalence of Toxocara canis among Orang Asli (aborigines) in Peninsular Malaysia. Southeast Asian J. trop. Med. publ. Hlth., 23: 493-496, 1992.

22. HERRMANN, N.; GLICKMAN, L.T.; SCHANTZ, P.M.; WESTON, M.G. \& DOMANSKI, L.M. - Seroprevalence of zoonotic toxocariasis in the United States: 1971-1973. Amer. J. Epidem., 122: 890-896, 1985.

23. HOLLAND, C.; O'CONNOR, P.; TAYLOR, M.R.H. et al. - Families, parks, gardens and toxocariasis. Scand. J. infect. Dis., 23: 225-231, 1991.

24. HOLLAND, C.V.; O'LORCAIN, P.; TAYLOR, M.R.H. \& KELLY, A. - Seroepidemiology of toxocariasis in school children. Parasitology, 110: 535-545, 1995.

25. JACOBS, D.E.; WOODRUFF, A.W.; SHAH, A.I. \& PROLE, J.H. - Toxocara infections and kennel workers. Brit. med. J., 1: 51, 1977.
26. LJUNGSTROM, I. \& van KNAPEN, F. - An epidemiological and serological study of Toxocara infection in Sweden. Scand. J. infect. Dis., 21: 87-93, 1989.

27. LYNCH, N.R.; EDDY, K.; HODGEN, A.N.; LOPEZ, R.I. \& TURNER, K.J. Seroprevalence of Toxocara canis infection in tropical Venezuela. Trans. roy. Soc. trop. Med. Hyg., 82: 275-281, 1988.

28. MAGNAVAL, J.F.; GLICKMAN, L.T.; DORCHIES, P. \& MORASSIN, B. - Highlights of human toxocariasis. Korean J. Parasit., 39: 1-11, 2001.

29. MAGNAVAL, J.F.; GLICKMAN, L.T. \& DORCHIES, P. - La toxocarose, une zoonose helmintique majeure. Rev. méd. Vét., 145: 611-627, 1994a

30. MAGNAVAL, J.F.; MICHAULT, A ; CALON, N. \& CHARLET, J.P. - Epidemiology of human toxocariasis in La Reunion. Trans. roy. Soc. trop. Med. Hyg., 88: 531-533, 1994b.

31. MASTRANDREA, G. \& MICARELLI, A. - Ricerca parassitaria nei prodotti vegetali prevati da alcuni mercati rionali della cittá de Roma. Arch. ital. Sci. med. trop., 49: 55-59, 1968.

32. MATOS, M. de F.; MILITÃO, D.N.; BRUM, M.A. et al. - Presence of anti-Toxocara antibodies in children selected at Hospital Universitário, Campo Grande, MS, Brazil. Rev. Inst. Med. trop. S. Paulo, 39: 49-50, 1997.

33. MATSUMURA, K. \& ENDO, R. - Seroepidemiological study of toxocaral infection in man by enzyme-linked immunosorbent assay. J. Hyg. (Lond.), 90: 61-65, 1983.

34. MINVIELLE, M.C.; TAUS, M.R.; RAFFO, A.; CIARMELA, M.L. \& BASUALDO, J.A. - Seroprevalence of toxocariasis in blood donors of Gualeguaychú, Argentina. Trans. roy. Soc. trop. Med. Hyg., 94: 373-375, 2000

35. MIZGAJSKA, H. - The role of some environmental factors in the contamination of soil with Toxocara spp. and other geohelminth eggs. Parasit. Int., 46: 67-72, 1997.

36. OVERGAAUW, P.A.M. - Aspects of Toxocara epidemiology: human toxocarosis. Crit. Rev. Microbiol., 23: 215-231, 1997.

37. RADMAN, N.E.; ARCHELLI, S.M.; FOUROUGE, R.D.; GUARDIS, M. del V. \& LINZITTO, O.R. - Human toxocarosis. Its seroprevalence in the City of La Plata. Mem. Inst. Oswaldo Cruz, 95: 281-285, 2000.

38. SCHANTZ, P.M. - Toxocara larva migrans now. Amer. J. trop. Med. Hyg., 41(suppl.): 21-34, 1989.

39. SCHANTZ, P.M.; WEIS, P.E.; POLLARD, Z.F. \& WHITE, M.C. - Risk factors of toxocaral ocular larva migrans: a case-control study. Amer. J. publ. Hlth., 70: 1269$1272,1980$.

40. SCHULZ, S. \& KROEGER, A. - Soil contamination with Ascaris lumbricoides eggs as an indicator of environmental hygiene in urban areas of north-east Brazil. J. trop. Med. Hyg., 95: 95-103, 1992.

41. SNYDER, C.H. - Visceral larva migrans; ten years'experience. Pediatrics, 28: 85-91, 1961

42. SURGAN, M.H.; COLGAN, K.B.; KENNETT, S.I. \& PAFFMANN, J.V. - A survey of canine toxocariasis and toxocaral soil contamination in Essex County, New Jersey. Amer. J. publ. Hlth., 70: 1207-1208, 1980.

43. WOODRUFF, A.W.; DE SAVIGNY, D.H. \& JACOBS, D.E. - Study of toxocaral infection in dog breeders. Brit. med. J., 2: 1747-1748, 1978

44. WOODRUFF, A.W.; DE SAVIGNY, D.H. \& HENDY-IBBS, P.M. - Toxocaral and toxoplasmal antibodies in cat breeders and in Icelanders exposed to cats but not to dogs. Brit. med. J., 284: 309-310, 1982.

Received: 10 December 2001

Accepted: 15 October 2002 